4. Must A, Jacques PF, Dallal GE, Bajema CJ, Dietz WH. Long-term morbidity and mortality of overweight adolescents. A follow-up of the Harvard Growth Study of 1922 to 1935 . N Engl J Med. 1992;327:1350-5.

5. Sinaiko AR, Donahue RP, Jacobs DR Jr., Prineas RJ. Relation of rate of growth during childhood and adolescence to fasting insulin, lipids, and systolic blood pressure in young adults. Circulation. 1999;99:1471-6.

6. Ogden CL, Flegal KM, Carroll MD, Johnson CL. Prevalence and trends in overweight among US children and adolescents, 1999-2000. JAMA. 2002;288:1728-32.

7. Sinaiko AR, Steinberger J, Moran A, Hong CP, Prineas RJ, Jacobs DR Jr. Influence of insulin resistance and BMI at age 13 on systolic blood pressure, triglycerides and HDL-C at age 19. Hypertension. 2006;48:730-6.

8. Montague CT, O'Rahilly S. The perils of portliness: causes and consequences of visceral adiposity. Diabetes. 2000;49:883-8.

9. Ferreira AP, Oliveira CE, França NM. Metabolic syndrome and risk factors for cardiovascular disease in obese children: the relationship with insulin resistance (HOMA-IR). J Pediatr (Rio J). 2007;83:21-6.
10. Cook S, Weitzman M, Auinger P, Nguyen M, Dietz WH. Prevalence of a metabolic syndrome phenotype in adolescents: findings from the third National Health and Nutrition Examination Survey, 1988-1994. Arch Pediatr Adolesc Med. 2003;157:821-7.

11. Kahn R, Buse J, Ferrannini E, Stern M; American Diabetes Association; European Association for the Study of Diabetes. The metabolic syndrome: time for a critical appraisal: joint statement from the American Diabetes Association and the European Association for the Study of Diabetes. Diabetes Care. $2005 ; 28: 2289-304$.

12. Ferrannini E, Mari A. How to measure insulin sensitivity. J Hypertens. 1998;18:895-906.

13. Balkau B, Charles MA. Comment on the provisional report from the WHO consultation. European Group for the Study of Insulin Resistance (EGIR). Diabet Med. 1999;16:442-3.

\title{
The quality of care of very low birth weight babies in Brazil
}

\author{
Fernando C. Barros, ${ }^{1}$ José Luis Diaz-Rossello²
}

$T_{\text {h }}$ ting paper on health services research, analyzing the mortality of very low birth weight (VLBW) babies born in maternity hospitals with neonatal intensive care units (NICU) in 2002-2003, in Fortaleza, Ceará, Brazil. ${ }^{1}$ As the authors rightly state, this birth weight group, although being less than $2 \%$ of the total live births, require a highquality hospital care and account for a substantial and growing proportion of neonatal and infant mortality.

1. Pediatra y epidemiólogo. Consultor, Centro Latinoamericano de Perinatología y Desarrollo Humano (CLAP), Organización Panamericana de la Salud/Organización Mundial de la Salud (OPAS/OMS), Montevideo, Uruguay.

2. Pediatra neonatólogo. CLAP, OPAS/OMS, Montevideo, Uruguay. Profesor, Facultad de Medicina, Universidad de la Republica, Montevideo, Uruguay.

Suggested citation: Barros FC, Diaz-Rossello JL. The quality of care of very low birth weight babies in Brazil. J Pediatr (Rio J). 2007;83(1):5-6.

doi:10.2223/JPED.1586
The paper shows that the neonatal and overall hospital mortality rates of Fortaleza's VLBW babies are much higher than those observed in a network of NICUs in the United States, for all birth weight groups. ${ }^{2}$ Birth weightspecific intrahospital mortality is an indicator of quality of care and this initial comparison with NICUs of a highly developed country may put the target too far. However, the authors also show that the mortality rates in Fortaleza are higher, for all birth weight groups, than those observed in Montevideo, Uruguay. ${ }^{3}$ Here we should be much more concerned about the magnitude of our avoidable deaths, considering that there are no relevant differences in the available technology and human resources for the care of newborns between the two cities.

After the publication of these interesting results, what should be the next steps to identify gaps in the quality of care in Fortaleza's NICUs in order to prevent avoidable deaths? One first element would be to compare the units participating 
in the current study - three public and five private hospitals by looking at their birth weight-specific and gestational-agespecific mortality rates and evaluating their quality of care, measured by different dimensions - physical areas, human resources (nurses, medical neonatologists and other staff), prevalence of use of evidence-based interventions, equipment and family participation. It is well probable that the authors will find that there are NICUs in Fortaleza with better quality of care, and others that need help to correct their problems. The information is now available to be used confidentially to produce the necessary changes.

Another interesting exercise would be to compare, using a common minimal data set, the findings of the Fortaleza study (and those from the forthcoming NorthernNortheastern Perinatal Network) with similar information from other Brazilian NICUs, especially those from the Brazilian Network of Neonatal Research, ${ }^{4,5}$ which covers an important number of institutions mostly in southern and southeastern Brazil. Besides comparing the characteristics of the mothers and babies assisted in these units, this study would provide vital information on the quality of care of a large number of NICUs in the country, and identify areas that need rapid improvement in order to decrease the large number of Brazilian babies who still die of avoidable causes. Further decreases in infant mortality in Brazil will depend largely on the reduction of neonatal mortality, and the permanent monitoring and improvement of the quality of care of small babies is a key element.

\section{References}

1. Castro EC, Leite AJ. Hospital mortality rates of infants with birth weight less than or equal to $1,500 \mathrm{~g}$ in the northeast of Brazil. J Pediatr (Rio J). 2007; 83:27-32.

2. Horbar JD. The Vermont Oxford Trials Network 2002. Annual Report Burlington. Vermont: Network; 2003.

3. Forteza C. Morbi-mortalidad en recién-nacidos menores de $1500 \mathrm{~g}$ en la ciudad de Montevideo, Uruguay [dissertation]. Pelotas: Universidade Federal de Pelotas; 2000.

4. Rede Brasileira de Pesquisas Neonatais. Uso antenatal de corticosteróide e evolução clínica de recém-nascidos pré-termo. J Pediatr (Rio J). 2004;80:277-84.

5. Leone CR, Sadeck LSR, Vaz FC, Almeida MFB, Draque CM, Guinsburg $R$, et al. Brazilian Neonatal Research Network (BNRN): very low birth weight (VLBW) infant morbidity and mortality. Pediatr Res. 2001;49:405A. 